\title{
The Benefits of Culture-Themed Literacy Books on Learning to Write Interviews Text on Elementary School Students
}

\author{
Sefri Rahma Wardani* \\ Magister Pendidikan Bahasa Indonesia \\ Universitas Sebelas Maret Surakarta \\ Surakarta, Indonesia \\ sefrirahmaw@student.uns.ac.id
}

\author{
Andayani \\ Magister Pendidikan Bahasa Indonesia \\ Universitas Sebelas Maret Surakarta \\ Surakarta, Indonesia \\ bu_anda09@yahoo.co.id
}

\author{
Suyitno \\ Magister Pendidikan Bahasa Indonesia \\ Universitas Sebelas Maret Surakarta \\ Surakarta, Indonesia \\ yitsuyitno52@gmail.com
}

\begin{abstract}
Culture-themed literacy books are one type of literacy books found in elementary schools. The aim of this research is to determine the benefits of culture-themed literacy books in learning to write interview texts in language learning. This research is qualitative. The samples of this research were culture-themed literacy books for elementary schools. The data were collected using the literature review, reading, note taking, and interview techniques. The analyzed data were the interview texts in culture-themed literacy books. The date was validated using the triangulation of theories and sources. The steps of analysis consist of data reduction, data presentation, and conclusion drawing/verification. It was found that culturethemed literacy books describe real interview activities and have benefits in language learning, especially in learning to write interview texts for elementary school students.
\end{abstract}

Keywords - literacy book, learning, interview text.

\section{INTRODUCTION}

Elementary school students are the students at the primary education level who really need guidance from adults. The stage of elementary education is the initial education students get. This is essential to shape the character of students. If elementary education cannot equip students with good contents, they will not be able to reflect on the good attitude as expected.

Based on the case that occurred in the field, it was found that many students still need to get moral training to form a better character. The case in Indonesia is that many students can not apply the principles of communication and attitudes to be displayed in communication well. Many say that this is due to different times and eras, but apart from that there are solutions that can be used to improve students' attitudes in communication. There are many ways to support the development of elementary school students, one of which is providing books with a good content for them. This is expected to be a guide and regulator of students in determining attitudes when they communicate with others. If students are accustomed to getting good culture or values, they will get used to getting or doing good things. Such actions can also be called forms of character education. This can make all aspects integrated in forming a positive effect. This is as revealed by the US Department of Education Contract (2007: 3) that education to form good attitudes, or what is often called character education, is a term used to embrace all aspects of how schools, social institutions and parents can support the positive development of children's and adults' characters.

In addition, the school is the right place to apply new knowledge or culture to children. This is in accordance with the statement of Muursepp.and.Kikkul (2014: 375) that the school is a meeting place for children who develops very fast, so the habituation experienced by them is also very influential. Thus, teachers should use media to provide positive things related to their interview skills.

One of the media that can be used is the culturethemed literacy book provided by the government. It contains data on traditional houses in Indonesia. This book contains much information about traditional houses in Indonesia that can arouse students' curiosity about that information because in the book are illustrations that support in the interview learning because not all elementary schoolage children currently have the courage to ask what they want to know to others. The existence of the writing interview text material at the elementary school level is expected to improve students' skills in asking or digging for information.

Therefore, the existence of a culture-themed literacy book can provoke creativity and bring up students' skills, especially in digging up information about cultural heritage objects such as traditional houses of the archipelago.

\section{METHOD}

This research uses a qualitative research method. According to Creswell (2007: 37; 2009: 4), a qualitative research is the research that tries to examine social problems both individuals or groups. This research examines social problems regarding education. The samples of this research were culture-themed literacy books at elementary schools. The list of culture-themed literacy books used in this research is as follows.

TABLE 1. LIST OF BOOKS USED IN RESEARCH

\begin{tabular}{|l|l|l|}
\hline Title & Writer & Publisher \\
\hline Berselancar ke 34 & Kiki Ratnaning & Badan \\
Rumah Adat & Arimbi & $\begin{array}{l}\text { Pengembangan } \\
\text { dan Pembinaan } \\
\text { Indonesia Yuk! }\end{array}$ \\
& & Bahasa \\
\hline
\end{tabular}




\begin{tabular}{|c|c|c|}
\hline $\begin{array}{l}\text { Mengenal } \\
\text { Rancang Bangun } \\
\text { Rumah Adat di } \\
\text { Indonesia }\end{array}$ & Faris Al Faisal & $\begin{array}{l}\text { Badan } \\
\text { Pengembangan } \\
\text { dan Pembinaan } \\
\text { Bahasa }\end{array}$ \\
\hline $\begin{array}{ll}\text { Rumah } & \text { Adat } \\
\text { Nusantara } & \end{array}$ & $\begin{array}{l}\text { Nindya } \\
\text { Suwarto }\end{array}$ & $\begin{array}{l}\text { Badan } \\
\text { Pengembangan } \\
\text { dan Pembinaan } \\
\text { Bahasa }\end{array}$ \\
\hline
\end{tabular}

The data in this research are the benefits of culturethemed literacy books in learning to write interview texts. Altheide and Schineider (2013: 1) say that the qualitative research is developed by searching through books, journals, in-depth interviews, curriculum vitae, autoetnography, and analysis. The data collection technique used in this research was the literature review on previous researches and references related to the use of culture-themed literacy books in language learning especially, writing interview texts. Then, the reading technique was used to find evidence that culture-themed literacy books have benefits in learning to write interview texts. Meanwhile, the note-taking technique was to note important things found during the observation or review of books and in interviews. Further interviews were conducted with the elementary school teachers in urban and rural areas. Data validity used triangulation of theories and sources. Relevant theories to the research were used for theory triangulation while the source triangulation used two data sources, namely the informant and the literacy book itself. This is consistent with the statement of Cohen, Manion, and Morrison (2000: 112) that triangulation is the use of two or more data collection methods to collect research data. Miles and Huberman (1994: 16) state that data analysis consists of three activities carried out simultaneously, namely data reduction, data presentation, and conclusion drawing/verification. The data analysis consists of sorting out the data needed, presenting the data, and concluding the research results from the data obtained. The initial step used in this research was to choose a literacy book to be used in this research. It was then studied to find illustrations that support learning to write interview texts and the researcher chose the data needed in the research. After the data had been collected, they were presented. Based on the data, the research findings were then drawn up.

\section{RESULT}

The data from this research indicate that culturethemed literacy books have benefits in learning Indonesian language in elementary schools. The material that gets direct benefit from the existence of the literacy book is the material of writing interview texts on the fourth-grade students of elementary schools. This is in line with the syllabus used in elementary schools about writing interview texts.

\section{Illustration of Interview Activities in Culture-Themed Literacy Books}

Literacy books used as the research objects have information in the form of the data on the archipelago traditional houses characteristics which can be a reference to obtain the data during interviews. In addition, there are culture-themed literacy books, almost all of whose explanations about the traditional house of the archipelago use narration that illustrates the twin characters who visit 34 traditional houses to conduct interviews. This can be seen in the following table.

TABLE 2. ILLUSTRATION OF INTERVIEW IN CULTURE-THEMED LITERACY BOOKS

\begin{tabular}{|c|c|}
\hline Section & Illustration \\
\hline Surfing 2 & $\begin{array}{l}\text { Visiting the house and interviewing Mr. } \\
\text { Boni about the traditional house of North } \\
\text { Sumatra. }\end{array}$ \\
\hline Surfing 5 & $\begin{array}{l}\text { Visiting the house and interviewing Mr. } \\
\text { Pasa about the traditional house of Riau } \\
\text { Islands. }\end{array}$ \\
\hline Surfing 12 & $\begin{array}{l}\text { Visiting Cikedokan and interviewing the } \\
\text { village chief about the traditional house } \\
\text { of West Java. }\end{array}$ \\
\hline Surfing 13 & $\begin{array}{l}\text { Visiting Banten and interviewing the } \\
\text { chief of the Baduy tribe. }\end{array}$ \\
\hline Surfing 16 & $\begin{array}{l}\text { Visiting East Java and interviewing Mr. } \\
\text { Narto who has the Joglo traditional } \\
\text { house of Situbondo. }\end{array}$ \\
\hline Surfing 17 & $\begin{array}{l}\text { Visiting the house and interviewing Mr. } \\
\text { Dhika about the traditional house of Bali. }\end{array}$ \\
\hline Surfing 22 & $\begin{array}{l}\text { Visiting the house and interviewing } \mathrm{Mr} \text {. } \\
\text { Danu about the traditional house of } \\
\text { South Kalimantan. }\end{array}$ \\
\hline Surfing 26 & $\begin{array}{l}\text { Visiting the house and interviewing the } \\
\text { Customary Head of West Sulawesi about } \\
\text { the traditional house of West } \\
\text { Kalimantan. }\end{array}$ \\
\hline Surfing 27 & $\begin{array}{l}\text { Visiting the house and interviewing } \mathrm{Mr} \\
\text { Andi about the traditional house of } \\
\text { Central Sulawesi. }\end{array}$ \\
\hline Surfing 32 & $\begin{array}{l}\text { Visiting North Maluku and interviewing } \\
\text { Mr. Ashar about the traditional house of } \\
\text { North Maluku. }\end{array}$ \\
\hline Surfing 34 & $\begin{array}{l}\text { Visiting Papua and interviewing Mr. } \\
\text { Didi about the traditional house of } \\
\text { Papua. }\end{array}$ \\
\hline
\end{tabular}

The material about archipelago traditional house is presented briefly in the form of an explanation of each traditional house in two other culture-themed literacy books. This explanation can be used as the material for the next interviews.

\section{Benefits of Culture-Themed Literacy Books in Learning}

The results of interviews with elementary school teachers in Kebumen Regency concluded that the culturethemed literacy book has benefits in learning Indonesian language. One of the materials in Indonesian language that is useful is writing interview texts to be mastered by the student

The culture-themed literacy book contain illustrations of conducting interviews by children who have an adventure to find information about traditional homes. The illustrations contained in the book can be a guide for children in conducting interviews. In addition, this can also 
be the learning of children who want to conduct interviews with people who have different cultural backgrounds.

\section{DISCUSSION}

According to Jarvis (2004: 140), learning is considered as the most important element in education defined as the learning process to limit cultural transmission. Rossum and Hamer (2010: 4) add that learning is the same as the process of memorization and the ability to reproduce what memorization is usually done at school. Based on these statements, it can be interpreted that learning can be used as an activity to determine the culture that students need to learn as a provision of knowledge. In addition, learning also means something that is learned, understood, and memorized as the learning material at school.

\section{Illustration of Interview Activities in Culture-Themed Literacy Books}

Cultural-themed literacy books have benefits in learning to write interview texts. There are sections in the literacy book that illustrate the story of twins who interviewed several customary heads of an area to get the information about traditional houses.

This book contains things that must be learned and understood in schools about cultures that students need to know. One of them is the culture of conducting interviews, Even when $f$ the interview is conducted on people who live in different areas and have different habits or cultures from students.

The interview activities carried out are in sections $2,5,12,13,16,17,22,26,27,32$, and 34 . They visit several traditional chief houses to get the information about traditional houses throughout the archipelago. Step by step interviews that are used to gather information from regional leaders are good examples of interviews for elementary school students.

The description of the story can be an example of how to visit and dig in information well and politely from the interviewees during the interviews. This can be seen from the delivery from beginning to end when the characters carry out visits for interviews. They use polite and gradual language.

First they met with the speakers, they said their greetings, then when they looked around the traditional houses, they asked questions that needed to be asked politely. The attitude needs to be emulated by children in conducting interviews to continue to put forward the attitude of courtesy.

The actors in the literacy book also appreciate the dish or habit of the host in treating a guest. After they had finished digging up the information, they said goodbye. This can be used as a reference when conducting interviews with the respondents.

This kind of attitude is very useful for students as a reference in conducting interviews or gathering information to other people/respondents. When conducting the interviews, the students have a picture that is used as a guide in conducting interviews as illustrated in the culture-themed literacy book. This is consistent with what the statement of
Hiebert and Raphael (2013: 7) that literacy as a language process can build what children have already known and expand children's knowledge about language. Thomas and Jolls (2005: 6) add that literacy education can be used as an attractive bridge because students can learn to criticize the things they need and to accompany their learning process towards the future. Culture-themed literacy books used in this research can be the media to expand children's knowledge about interviews as supporting textbooks.

Each community has different habits or customs, so students can learn about the customs and habits of a tribe from the book. They will have a picture of the habits of a tribe. Geertz (1773: 17) states that culture is a symbol of a system that has an internal relationship between the elements that characterize the whole organized system. This can be used as a guide for students in conducting interviews to better respect others related to their habits because the culture of an area will reflect the area itself.

This knowledge is needed for students to be more careful in acting. Each region has a different character and habit. Students must be able to adjust with any one and the habits possessed by the interlocutor or respondent when conducting interviews. This is as stated by Koentjaraningrat (2000: 181) that culture is "power" in the form of creativity, initiative and a sense of the community, so the characters and habits of each region can be different.

\section{Benefits of Culture-Themed Literacy Books in Learning}

The results of the interviews with elementary school teachers imply that this culture-themed literacy book has benefits in language learning. The material that benefits directly from this book is writing interview texts. This material is in the syllabus found in elementary schools.

Elementary school students consisting of the students at the primary education level still need the guidance from the teacher. The teacher must be able to determine the appropriate learning media used by the students. The learning media used must be appropriate to support the material given to the school.

Cultural-themed literacy books can be used as learning media for constructing interview texts. This book has illustrations of elementary school students who conduct interviews in several places to get information about traditional houses. The description of interviews conducted by the students can be used as an example for students in conducting interviews.

The contents of the literacy book can be a reference for students in conducting interviews. If they need examples or descriptions of interview activities, they can study the illustrations of interview activities in the literacy book.

After they have read the adventure stories of the characters in the culture-themed literacy book, the students have knowledge about the interview. They understand the sequence that must be done in digging in information from others.

This book helps teachers add students' references to interviews. They can take this knowledge to practice. This shows that students get positive things to improve their skills to write interview texts after reading the examples in the book. 
The existence of this book has benefits to support learning to write interview texts. Students have a reference to enrich their insights in learning to write interview texts.

The research that is relevant to this is the research conducted by Whitehead entitled Justifying the Design and Selection of Literacy and Thinking Tools in 2008. This research contains criteria for design and tools used by teachers and schools in supporting literacy programs. The similarity with this research is that both are about the media used by the teacher. However, the difference is that in the Whitehead's research, the researcher examines the literacy media while in this research we focus on literacy media to support learning.

The next relevant research is the research conducted by Foran, Mannion, and Rutherford in 2017 with the title Focusing Elementary Students with Active Classroom: Exploring Teachers' Perceptions of Self-Initiated Practices. The relevance of the previous research with this research is both are related to elementary schools and focus on cultural aspects. The research conducted by the researcher also contains cultural elements found in the social environment when conducting interviews.

Vasbo in 2013 conducted a research under the title Intercultural Learning Across Contexts. The relevance of Vasbo's research with the current research is that both are about the culture contained in the school environment, which departs from a complex and multicultural social reality. The difference is that Vasbo explores young people's experiences during a student exchange program while in the current research is about the culture to consider when conducting interviews.

\section{CONCLUSION}

All in all, culture-themed literacy books have benefits in language learning i.e. in writing interview texts. The book has illustrations of conducting interviews. This culturalthemed literacy book has benefits in language learning in writing interview texts. The things that can be used as guidelines in the book are steps for conducting interviews, actions taken when collecting information, and actions to respect differences in habits between the interviewer and the respondent. Therefore, the students have more knowledge in language learning in constructing interview texts.

\section{REFERENCES}

Altheide, D.L and Christopher J.S.(2013).Qualitative Media Analysis. United States of America: Sage publications Inc.

Cohen, L., Manion, L., and Morrison, K.(2000).Research Methods in Educations. Prancis: Routletge Falmer.

Creswell, J.W.(2007).Qualitative Inquiry \& Research Design Choosing Among Five Approaches. California:Sage Publications.

Creswell, J.W.(2009).Research Design: Qualitative, Quantitative, and Mixed Methods Approaches. London:Sage Publications.

Foran, C.A., Mannion, C., and Rutherford, G.(2017). Focusing Elementary Students with Active Classroom: Exploring Teachers Perceptions of Self-Initiated Practices. International Electronic Journal of Elementary Education, 10(1), 61-69.

Geertz,C.(1973). The Interpretation of Cutures. New York: Basic Book Inc.

Hiebert, E.H. and Raphael, T.E.(2013).Early Literacy Instruction. California:Text Project Inc.

J. Clerk Maxwell. (1892). A Treatise on Electricity and Magnetism. Oxford: Clarendon.

Jarvis, P.(2000). Adult Education and Lifelong Learning. London: Routletge Farmer.

Koentjaraningrat. (2000). Pengantar Ilmu Antropologi. Jakarta: Radar Jaya Offset.

Miles, M.B. and A. M. Huberman.(1994).Qualitative Data Analysis :An Expanded Sourcebook. London : Sage Publication.

Muursepp, Mare and Kikkull, Andry. (2014). Cooking and Hammering: Primary School Pupils' Concepts of their Craft Skills. International Electronic Journal of Elementary Education, 6(3), 371-384.

Thomas, Elizabeth and Jolls, Tessa.(2005).Literacy for the 21st Century:An Overview \& Orientation Guide to Media Literacy Education. Spanyol: Center for Media Literacy.

US Departemen of Education Contract. (2007). Mobilizing for Evidence Based Character Education. United States: US Departemen of Education Contract.

Whitehead, David.(2008). Justifying the Design and Selection of Literacy and Thinking Tools. International Electronic Journal of Elementary Education, vol. 1(1), 34-51.

Vasbo, K.B. (2013). Intercultural Learning Across Contexts. International Electronic Journal of Elementary Education, 6(1), 83-94. 